University of Nebraska - Lincoln

DigitalCommons@University of Nebraska - Lincoln

Papers in the Earth and Atmospheric Sciences

Earth and Atmospheric Sciences, Department

\title{
Lithostratigraphy of the late Early Permian (Kungurian) Wandrawandian Siltstone, New South Wales: Record of glaciation?
}

S. G. Thomas

Southern Methodist University, sgthomas@smu.edu

Christopher R. Fielding

University of Nebraska-Lincoln, cfielding2@unl.edu

Tracy D. Frank

University of Nebraska-Lincoln, tfrank2@unl.edu

Follow this and additional works at: https://digitalcommons.unl.edu/geosciencefacpub

Part of the Earth Sciences Commons

Thomas, S. G.; Fielding, Christopher R.; and Frank, Tracy D., "Lithostratigraphy of the late Early Permian (Kungurian) Wandrawandian Siltstone, New South Wales: Record of glaciation?" (2007). Papers in the Earth and Atmospheric Sciences. 105.

https://digitalcommons.unl.edu/geosciencefacpub/105

This Article is brought to you for free and open access by the Earth and Atmospheric Sciences, Department of at DigitalCommons@University of Nebraska - Lincoln. It has been accepted for inclusion in Papers in the Earth and Atmospheric Sciences by an authorized administrator of DigitalCommons@University of Nebraska - Lincoln. 
Published in Australian Journal of Earth Sciences 54 (2007), pp. 1057-1071; doi: 10.1080/08120090701615717

Copyright ( 2007 Geological Society of Australia; published by Taylor \& Francis. Used by permission.

\title{
Lithostratigraphy of the late Early Permian (Kungurian) Wandrawandian Siltstone, New South Wales: Record of glaciation?
}

\author{
S. G. Thomas, C. R. Fielding, and T. D. Frank \\ Department of Geosciences, University of Nebraska-Lincoln, PO Box 880340, Lincoln, NE 68588, USA \\ Corresponding author - S. G. Thomas; present address: Department of Geological Sciences, \\ Southern Methodist University, PO Box 750395, Dallas, TX 75275, USA; email sgthomas@smu.edu
}

\begin{abstract}
The late Early Permian (273-271 Ma) Wandrawandian Siltstone in the southern Sydney Basin of New South Wales represents a marine highstand that can be correlated over $2000 \mathrm{~km}$. A mainly fine-grained terrigenous clastic succession, the Wandrawandian Siltstone contains evidence for cold, possibly glacial conditions based on the presence of outsized clasts and glendonites, mineral pseudomorphs after ikaite, a mineral that forms in cold $\left(0-7^{\circ} \mathrm{C}\right)$ marine sediments. A lithostratigraphic and facies analysis of the unit was conducted, based on extensive coastal outcrops and continuous drill-cores. Eight facies associations were identified: (i) siltstone; (ii) siltstone with minor interbedded sandstone; (iii) interbedded tabular sandstone and siltstone; (iv) admixed sandstone and siltstone to medium-grained sandstone; (v) discrete, discontinuous sandstone intervals; (vi) chaotic conglomerate and sandstone in large channel forms; (vii) chaotically bedded and pervasively soft-sediment-deformed intervals; and (viii) tuffaceous siltstone and claystone. Using lithology and ichnology, relative water depths were ascribed to each facies association. Based on these associations, the unit was divided into five informal members that reveal a history of significant relative sea-level fluctuations throughout the formation: member I, interbedded/admixed sandstone and siltstone; member II, siltstone; member III, slumped masses of members I and II; member IV, siltstone and erosionally based lensoid sandstone beds and channel bodies; and member V, interbedded/admixed sandstone and siltstone with abundant tuffs. Member I marks an initial marine transgression from shoreface to offshore depths. Member II records the maximum water depth of the shelf. Member III is interpreted to be a slump sheet; plausible mechanisms for its emplacement include seismicity produced by tectonism or glacio-isostatic rebound, changes in pore-water pressures due to sea-level fluctuations, or an increase in sedimentation rates. Members IV and V record minor fluctuations in depositional environments from offshore to shoreface water depths. Member IV includes regionally extensive, large channel bodies, with composite fills that are interpreted as storm-influenced mass-flow deposits. Member V includes a greater abundance of volcanic ash. Glacial controls (isostasy, eustasy) and tectonic affects may have worked in concert to produce the changes in depositional environments observed in the Wandrawandian Siltstone.
\end{abstract}

Keywords: Late Paleozoic Ice Age, lithostratigraphy, New South Wales, Permian, Sydney Basin, Wandrawandian Siltstone

\section{Introduction}

This paper provides a stratigraphic re-evaluation of the late Early Permian Wandrawandian Siltstone, a unit of the Shoalhaven Group in the southern Sydney Basin, New South Wales. The Wandrawandian Siltstone is exposed in coastal cliffs in the Illawarra region adjacent to the town of Ulladulla, further north around Jervis Bay and at isolated inland localities (Figure 1). It is placed stratigraphically in the upper part of the Lower to lower Middle Permian Shoalhaven Group (Figure 2), which is known for diverse lithologies and rich fossil assemblages. Despite the Shoalhaven Group having been considered as a target for petroleum exploration (Arditto 2001), no studies have in- cluded detailed measured stratigraphic sections and an internal correlation scheme for this outcrop belt. This study presents a comprehensive lithostratigraphic framework and paleoenvironmental interpretation for the Wandrawandian Siltstone.

Biostratigraphic data of Briggs (1998), based on abundant marine fossils, place the Wandrawandian Siltstone in the mid-Kungurian, $c a$. 273-271 Ma in age relative to the timescale of Gradstein et al. (2005) that is used in this paper. Several papers have described aspects of the lithostratigraphy (Gostin \& Herbert 1973, Ramli \& Crook 1978, Eyles et al. 1998), but interpretations regarding the origin of the Wandrawandian Siltstone have differed. Whereas Gostin \& Herbert (1973), Ramli \& Crook (1978), and Runnegar 
Figure 1. (a) Location of the Bowen-GunnedahSydney Basin System, a series of north-southtrending basins containing Lower Permian to Triassic strata. (b) Location of outcrop and borehole locations in the southernmost part of the Sydney Basin.

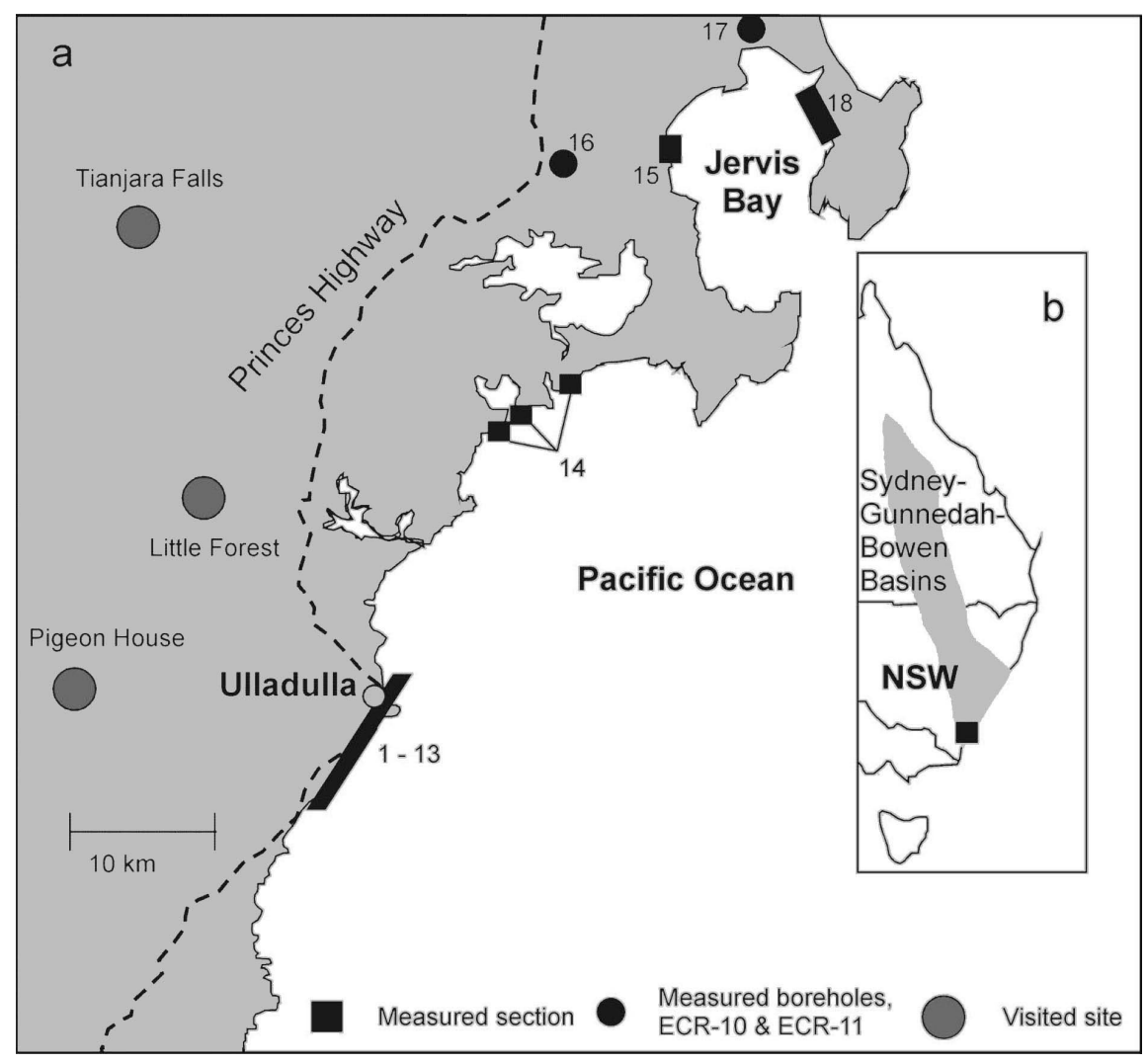

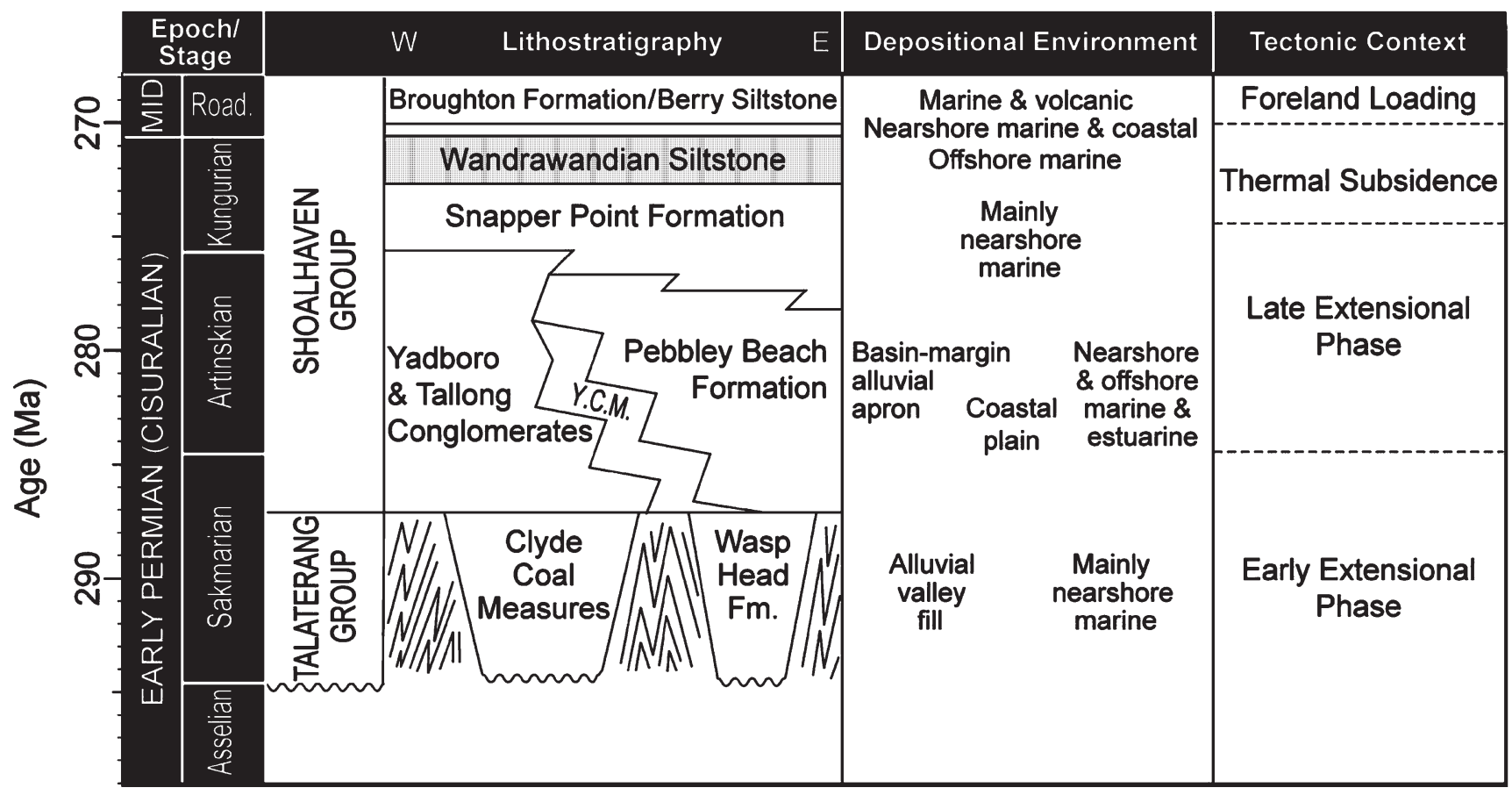

Figure 2. Stratigraphy of the Early Permian Talaterang Group and the Early to early Middle Permian Shoalhaven Group (after Tye et al. 1996). Associated tectonic setting is identified on the right. YCM, Yarrunga Coal Measures.

(1980) interpreted the Wandrawandian Siltstone to represent shelfal to embayed shallow marine conditions of modest depths, Eyles et al. (1998) ascribed an outer shelf to continental slope bathymetry to the Wandrawandian Siltstone based on the presence of the Cruziana and Zoophycos Ichno- facies assemblages and interpreted sediment gravity-flow (turbidite) deposits (Figure 2).

During the Permian, the Sydney Basin lay at high latitudes of $\sim 60-85^{\circ}$ on the Panthalassan margin of Gondwana (Powell \& Li 1994). Cool climatic conditions have been sug- 
gested for much of the deposition of the Shoalhaven Group based on the abundance of outsized, extraformational clasts in marine deposits, although disagreement remains over whether the Late Paleozoic Ice Age extended throughout its deposition (Veevers \& Powell 1987; Crowell 1999; Isbell et al. 2003).

Early studies of the Wandrawandian Siltstone (David et al. 1905; Brown 1925) first noted the presence of abundant outsized clasts interpreted as ice-rafted debris and glendonites, calcite pseudomorphs after ikaite, a mineral that forms in near-freezing waters (Pauly 1963; Suess et al. 1982). Uncertainty still exists regarding whether ice formed seasonally or was derived from more permanent ice sheets, and whether the source of the ice was proximal or distal. The presence of glacial conditions during the deposition of the Wandrawandian Siltstone has long remained equivocal, in part, because of a lack of evidence for coeval terrestrial glaciation (Herbert 1980).

The Sydney Basin is part of a larger system of northsouth elongate basins referred to as the Bowen-GunnedahSydney Basin System (Figure 1) (Fielding et al. 2001). A phase of crustal extension initiated basin formation through the development of grabens and half- grabens in New South Wales during the Early Permian (Scheibner 1974; Battersby 1981; Murray 1990; Fielding et al. 1990, 2001; Roberts et al. 2006). The late Kungurian to Roadian stages of the Permian were characterized by passive thermal subsidence (Fielding et al. 2001). marine transgression of regional extent initiated at the end of the deposition of the nearshore marine Snapper Point Formation and inundated terrestrial deposits in the southern Sydney Basin (Tye et al. 1996). Continuation of this transgression resulted in the deposition of the Wandrawandian Siltstone. Elsewhere in the Bowen-Sydney-Gunnedah Basins, this transgression is represented by equivalents of the Wandrawandian Siltstone that include the Branxton, Porcupine, Barfield, Ingelara, and Maria Formations and possibly the Moah Creek beds (Fielding et al. 2001).
The overlying Nowra Sandstone and Berry Siltstone were deposited in middle to upper shoreface and offshore marine water depths, respectively (Le Roux \& Jones 1994; Fielding et al. 2001). Foreland-loading-induced subsidence associated with the Hunter-Bowen Contractional Event is thought to have caused the marine flooding event at the base of the Berry Siltstone (Fielding et al. 2001). Shoshonitic volcanism in the Broughton Formation, the uppermost unit in the Shoalhaven Group, is interpreted to be a product of continental arc formation during the Middle Permian (Carr 1998).

\section{Field Methods}

The present study examined surface exposures of the Wandrawandian Siltstone from Wairo Beach in the south to Jervis Bay in the north (Figure 1). Around Ulladulla, these exposures are nearly continuous, and beds were physically traced to correlate sections. Where physical correlation was not possible, intervals of similar lithologies were matched. Data from two drill-cores (Figure 1) were incorporated into the analysis to provide additional stratigraphic control. A lithostratigraphic framework for the Wandrawandian Siltstone proposed on the basis of correlatable lithological changes enables the unit to be divided into five informal A members. This framework allows the origins of each member and the formation as a whole to be re-evaluated.

Fieldwork was conducted in three major areas (Figure 1; Table 1) along the coastal exposures in the vicinity of Ulladulla, from (i) Lagoon Head to Ulladulla North Head, (ii) along the coast of Jervis Bay, including Huskisson and Montague Roadstead, and (iii) at inland localities such as Tianjara Falls, Pigeon House, and the Little Forest Region. However, the Wandrawandian Siltstone is only well exposed along the coast and thins substantially westward, so that the inland exposures are no thicker than $\sim 10 \mathrm{~m}$. Despite a similarity between the inland and coastal exposures, the thinness of the section and the poor quality of

Table 1. Section number, locality name and UTM coordinates for measured sections and core.

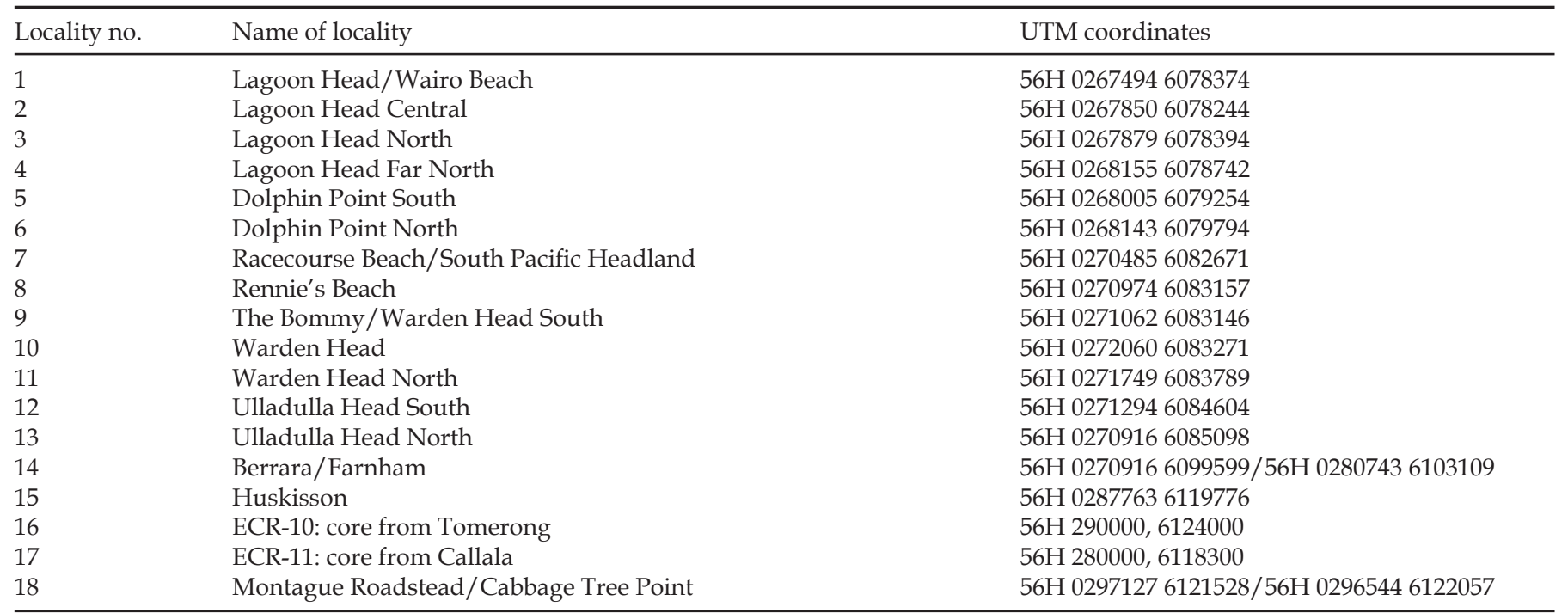

All sections and cores are on the Ulladulla 1:250 000 geological map sheet; sections are located on Figure 1. 
inland exposures preclude detailed correlation between the two. As a result, detailed sections were not measured at inland localities. Two boreholes from the Jervis Bay region, Elecom Clyde River (ECR)-10 and ECR-11 (Figure $1)$, were examined for additional stratigraphic control.

\section{Facies Analysis}

Based on lithology, sedimentary structures and tracefossil assemblages, eight facies associations are recognized in the Wandrawandian Siltstone: (i) siltstone; (ii) siltstone with minor interbedded sandstone; (iii) interbedded tabular sandstone and siltstone; (iv) admixed sandstone and siltstone to medium-grained sandstone; (v) discrete, discontinuous sandstone intervals; (vi) chaotic conglomerate and sandstone in large channel forms; (vii) chaotically bedded and pervasively soft-sediment-deformed intervals; and (viii) tuffaceous siltstone and claystone (Figure 3; Table 2).

Each facies association has a distinct trace-fossil assemblage (Table 2). Bioturbation intensity throughout the formation (Figure 4) is given in terms of the bioturbation index, a scale of 0-6 where 0 indicates no bioturbation, and 6 indicates complete bioturbation where no sedimentary structures are apparent (Reineck 1967; Taylor \& Goldring 1993; Bann 1998; Bann et al. 2004). When used in combination with sedimentology and paleontology, ichnofacies (trace-fossil assemblages) may be used to interpret paleoenvironmental conditions (Figure 4), including bathymetry (Seilacher 1964; Bromley 1996).

Outsized clasts are present throughout the Wandrawandian Siltstone, as are glendonites (Figure 4). Glendonites occur in discrete stratigraphic horizons (Figure 3). Three glendonite morphologies present in the Wandrawandian Siltstone are bladed, stellate and rosette forms (Figure 5). These morphologies appear to vary according to host-sediment lithology. Bladed forms, which are elongate and up to $30 \mathrm{~cm}$ in length, tend to be hosted in coarser lithologies ranging from admixed siltstone and sandstone to fine-grained sandstone. Rosettes are aggregates of smaller crystal forms (each 2-7 cm in diameter) that are typically confined to siltstone to silty fine-grained sandstone. Stellate morphologies are here defined as having two or three replaced crystal forms protruding from an elongate crystal form. Stellate morphologies are found associated with both blades and rosettes.

\section{Facies association 1: siltstone}

Description Facies association (FA) 1 comprises moderately to intensely bioturbated siltstone (bioturbation index
2-5) containing intact, delicate fossils including fenestrate and stony bryozoans, brachiopods with spines, articulated crinoid columnal stems, and rugose corals. The trace fossil assemblage, dominated by Helminthopsis, Zoophycos, and Cosmorhaphe, is considered to represent the Zoophycos Ichnofacies. Spherical and irregularly shaped carbonate nodules, which often enclose fossils or outsized clasts, are locally present. Glendonite rosettes are common in this facies, and stellate glendonites occur less frequently. Gravel- sized outsized clasts are also present throughout this facies. Fine laminations are present in less bioturbated strata.

Interpretation FA1 is interpreted to record shelfal water depths on an open marine continental margin. The presence of intact, delicate marine invertebrate fossils suggests deposition in quiet waters below storm wave-base. This is substantiated by the presence of the Zoophycos Ichnofacies, common among shelfal environments and facies (MacEachern et al. 1992a). Moderate bioturbation of these sediments indicates that the less- intensely burrowed, finely laminated muds may record modest rates of sediment deposition. The presence of fine laminations associated with little bioturbation suggests dysaerobic conditions (Savrda et al. 1984, Galloway \& Hobday 1996). Outsized clasts are interpreted as ice-rafted debris. Brown (1925) and Gostin \& Herbert (1973) noted the presence of faceted clasts in the outcrops at Ulladulla and suggested a glacial origin. No faceted clasts were found during this study. Glendonites in FA1 indicate bottom-water temperatures that were, at least seasonally, near-freezing.

\section{Facies association 2: siltstone with minor interbedded or admixed sandstone}

Description Although siltstone similar to FA1 dominates this facies, centimeter-scale sandstone interbeds and admixed sand are common. Bedsets are flat-lying in most areas, but a $7 \mathrm{~m}$ high foreset dipping to the east was noted at the north end of Rennie's Beach (Figure 6, Section 8). The eastward downlap is consistent with the interpreted direction of depositional deepening. Body fossils found in this association are also similar to those found in FA1. FA2 is moderately to intensely bioturbated (bioturbation index 24) and the trace fossils represent a distal expression of the Cruziana Ichnofacies. Rosette and stellate glendonites are present, and this association contains common cobble-to boulder- sized outsized clasts. FA2 also locally contains horizons of carbonate nodules.

Interpretation FA2 represents marine shelf to offshore environments of deposition. The thin sandstone inter- beds could reflect distal storm deposition. As in FA1, outsized clasts are interpreted as ice-rafted debris and glendonites as

\footnotetext{
Figure 3. [p. 1061] Outcrop photographs of major facies associations. (a) Coquinite in FA1, Warden Head (3 cm scale). (b) Siltstone with minor sand, FA2. Note dropstone horizon. Rennie's Beach. (c) FA3 (interbedded sand and silt) from Dolphin Point South. FA7 is also present. (d) FA4 with subtending Diplocraterion habichi burrows, Montague Roadstead ( $3 \mathrm{~cm}$ scale). (e) Lensoidal sand body of FA5. Maximum thickness is $\sim 2 \mathrm{~m}$. Lagoon Head Central. (f) FA6, Lagoon Head North. (g) FA3 and slumped sediments of FA7. The facies associations are separated by a slump scar, Warden Head. (h) $30 \mathrm{~cm}$ thick interval of FA8 from Cabbage Tree Point $(10 \mathrm{~cm}$ scale). People for scale in (b), (c), (f) and (g). See Table 1 for UTM coordinates.
} 

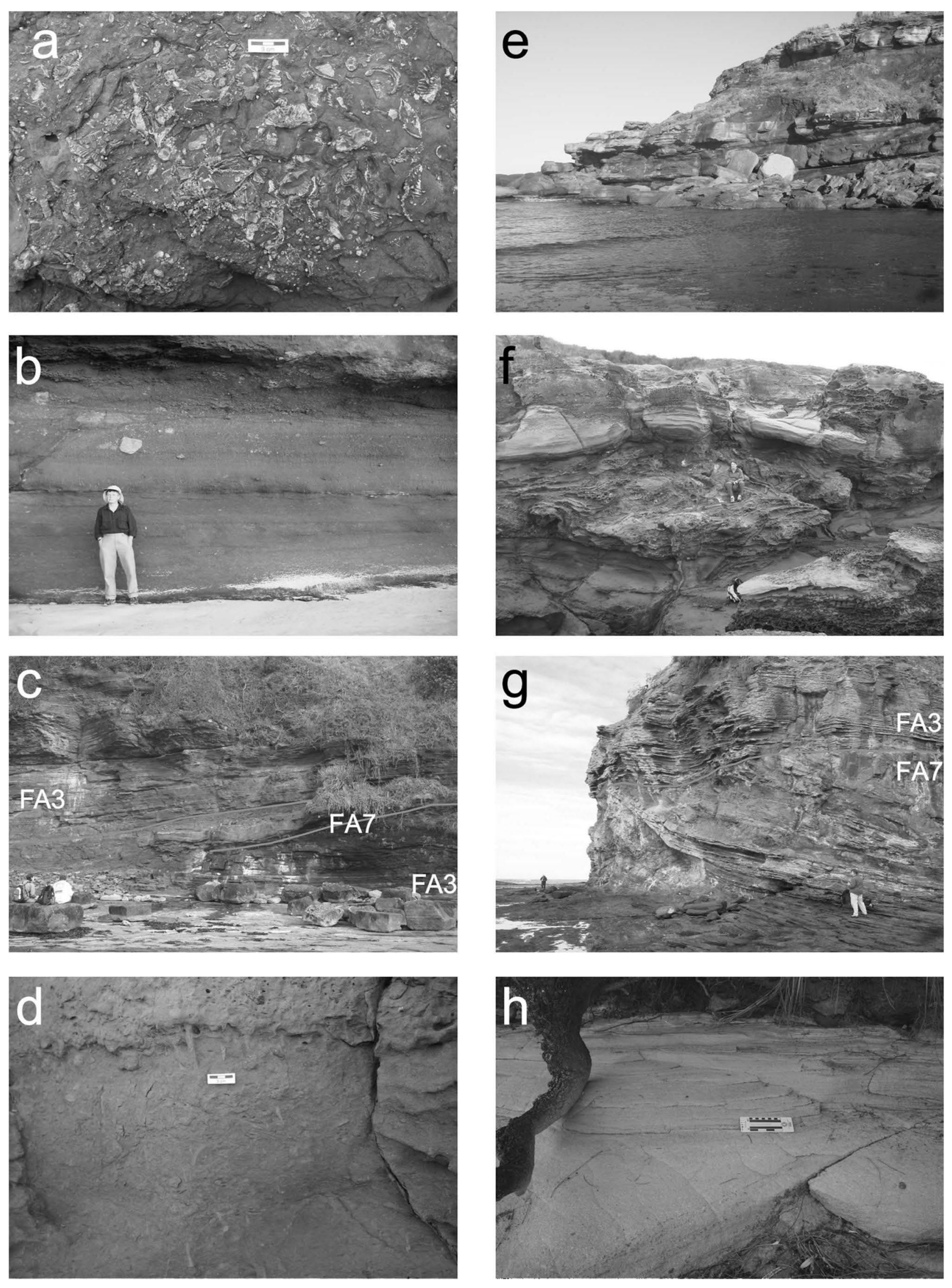


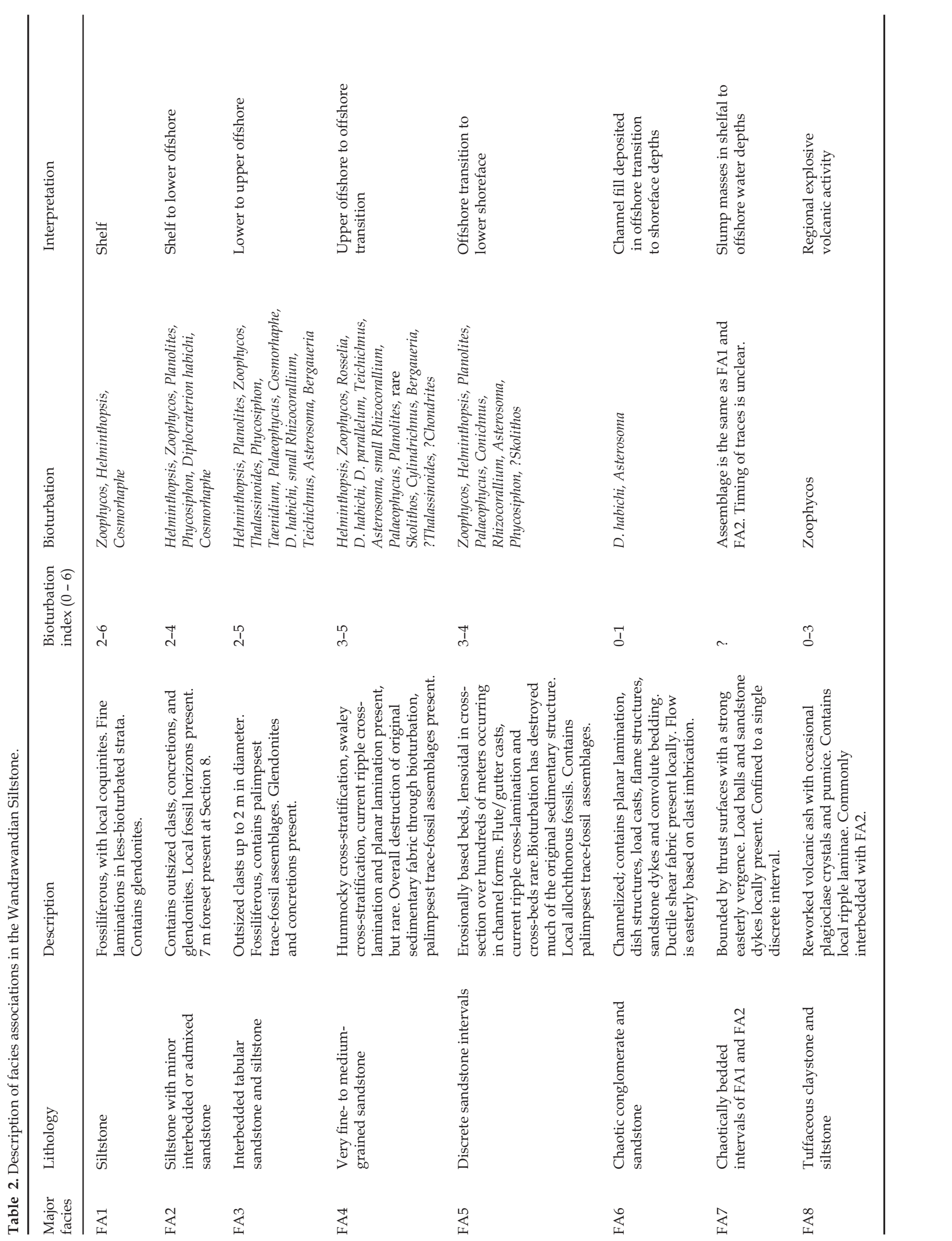


recording cold waters. Foresets present at Rennie's Beach may indicate progradation where sediment flux exceeded subsidence. The distal Cruziana Ichnofacies is consistent with a shelf to lower offshore interpretation (MacEachern et al. 1992a).

\section{Facies association 3: interbedded tabular sandstone and siltstone}

Description This facies association consists of interbedded tabular sandstone and siltstone similar to FA1. Centimeter-to decimeter-scale sandstone beds contain local hummocky cross-stratification and wave-modified current ripples, but stratification is typically modified to completely destroyed by bioturbation. Bioturbation ranges from minor to intense (bioturbation index 2-5) and is characterized by the Cruziana Ichnofacies. Diplocraterion habichi burrows subtend from the bases of many of the sandstones into the underlying siltstone, demarcating palimpsest assemblages, some of which include examples of the Glossifungites Ichnofacies (MacEachern et al. 1992b). FA3 locally contains fossil wood logs and rosette and stellate glendonites. Outsized clasts of up to $2 \mathrm{~m}$ in diameter are found in this association.

Interpretation The lithology, in combination with pervasive bioturbation and an overall lack of stratification, implies deposition of FA3 in upper offshore depths, although hummocky cross-stratification and current ripples in the tabular sandstone bodies indicate increased storminess. As in FA1 and FA2, outsized clasts and glendonites indicate the presence of ice and cold water temperature, respectively. The presence of palimpsest trace-fossil assemblages indicates that sediment supply was intermittent, allowing, at times, the development of a firm substrate. The presence of the Glossifungites Ichnofacies implies development of a cohesive, fine-grained substrate to allow excavation of vertical burrows that did not require support and were later filled by coarse-grained sediment (Frey \& Pemberton 1984). Palimpsest surfaces associated with the Glossifungites Ichnofacies may form in a variety of environments including those associated with sea-level fluctuations or a hiatus between depositional events, i.e. lower and more punctuated rates of sedimentation (MacEachern et al. 1992b).

\section{Facies association 4: admixed sandstone and siltstone to medium-grained sandstone}

Description FA4 (Figure 3) consists of moderately to pervasively bioturbated (bioturbation index 3-5), very fineto medium-grained sandstone with common admixed siltstone. Packages of FA4, typically $57 \mathrm{~m}$ in thickness, tend to fine upwards. The sandstone is considered to be a lithic wacke, indicating mineralogical and textural immaturity. The FA4 trace-fossil assemblage is diverse and is considered to represent a mixed Cruziana/Skolithos Ichnofacies (Table 2). Palimpsest assemblages are also present in this association. Sedimentary structures such as current ripple cross- lamination and planar lamination are rare. Glendon- ites are mainly bladed, with less common stellate forms. Carbonate nodules are locally present. Flattened coaly compressions of fossil wood are also found in FA4. At Cabbage Tree Point (Figure 1), beds of this facies fine upwards from silty fine sandstone to admixed sandstone and siltstone, and show discrete alternations between Zoophycos-dominated fine sandstone and Helminthopsis- and Cosmorhaphedominated admixed sandstone and siltstone.

Interpretation FA4 represents deposition in upper offshore to offshore transition depths. The overall nature of FA4 is bioturbated and structureless, although rare structures record current activity. The FA4 trace- fossil assemblage (Cruziana/Skolithos Ichnofacies) suggests an offshore transition bathymetry (Pemberton et al. 1992). The intensity of bioturbation suggests slow to moderate rates of deposition. Small-scale alternations between lithology and dominant trace fossils may reflect subtle changes in environment.

\section{Facies association 5: discrete, discontinuous sandstone intervals}

Description FA5 is composed of clean, quartzose sandstone lenses that reach hundreds of meters in width in cross-section and are decimeters to meters thick. These lensoidal beds are erosionally based, with common sole marks that include flute and gutter casts. Ripple cross-lamination and cross-bedding occurs locally in these beds. FA5 fines upwards from medium- grained sandstone to fine- or very fine-grained sandstone, and the tops of individual sandstone beds are characterized by a sharp contact. Bioturbation is common in FA5, and the bioturbation index ranges from 3 to 4 . Although FA5 is dominated by a Cruziana Ichnofacies, it contains additional vertical traces associated with the Skolithos Ichnofacies (Table 2). Palimpsest assemblages are also present. Small bladed and rosette glendonites ( $<5 \mathrm{~cm}$ long) are a rare component of this association, locally found only in the uppermost part of the sandstone.

Interpretation FA5 represents storm deposits in offshore transition to distal lower shoreface depths. Based on their broad, lensoidal geometry, FA5 sandstone bodies may be distal equivalents to the channels of FA6 defined below.

\section{Facies association 6: chaotic conglomerate and sandstone}

Description FA6 comprises channelized chaotic conglomerate and sandstone bodies, in units 5-10 $\mathrm{m}$ in total thickness (Figure 3). The channel bases of FA6 contain poorly sorted conglomerate, with extraformational lithic clasts, intraformational siltstone clasts, coaly plant debris, and large bivalves often preserved as moulds. Crude imbrication of these clasts indicates eastward paleoflow. The matrix is composed of silty sand in the lower beds, but FA6 passes upwards into quartzose sandstone. At Lagoon Head, a pervasive ductile shear fabric is present in pebbly sandstone above the basal erosion surface, overlain by intertonguing chaotic conglomerate and silty sand, followed by mud-draped sandstone. At Farnham Point, 


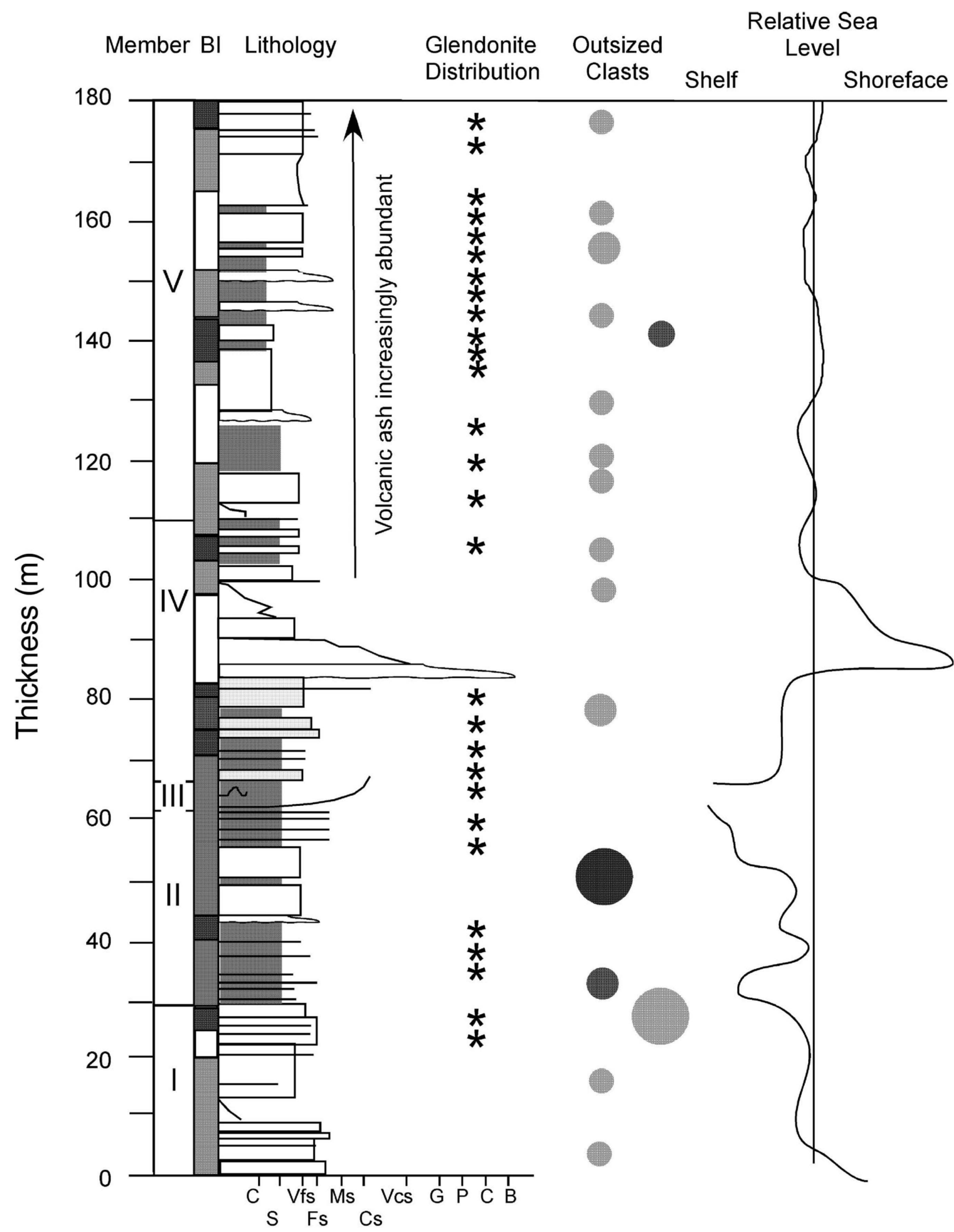

Figure 4. Composite log of the Wandrawandian Siltstone showing: lithology (C, clay; S, silt; Vfs, very fine-grained sandstone; Fs, fine-grained sandstone; Ms, medium-grained sandstone; Cs, coarse-grained sandstone; Vcs, very coarse-grained sandstone; G, granule; P, pebble; C, cobble; B, boulder); distribution of glendonites; outsized clast abundance (no fill, rare; grey, common; dark fill, abundant) and maximum size (circles correspond to pebble, granule, cobble and boulder sizes). A grey scale marks the bioturbation index (BI; after Reineck 1967; Taylor \& Goldring 1993; Bann et al. 2004) where no fill corresponds to BI of 0, and a dark fill corresponds to a BI of 5-6. The depositional environment curve was generated using facies associations, which were ascribed relative bathymetries using lithology, sedimentary structures and ichnofacies as described in the text. 

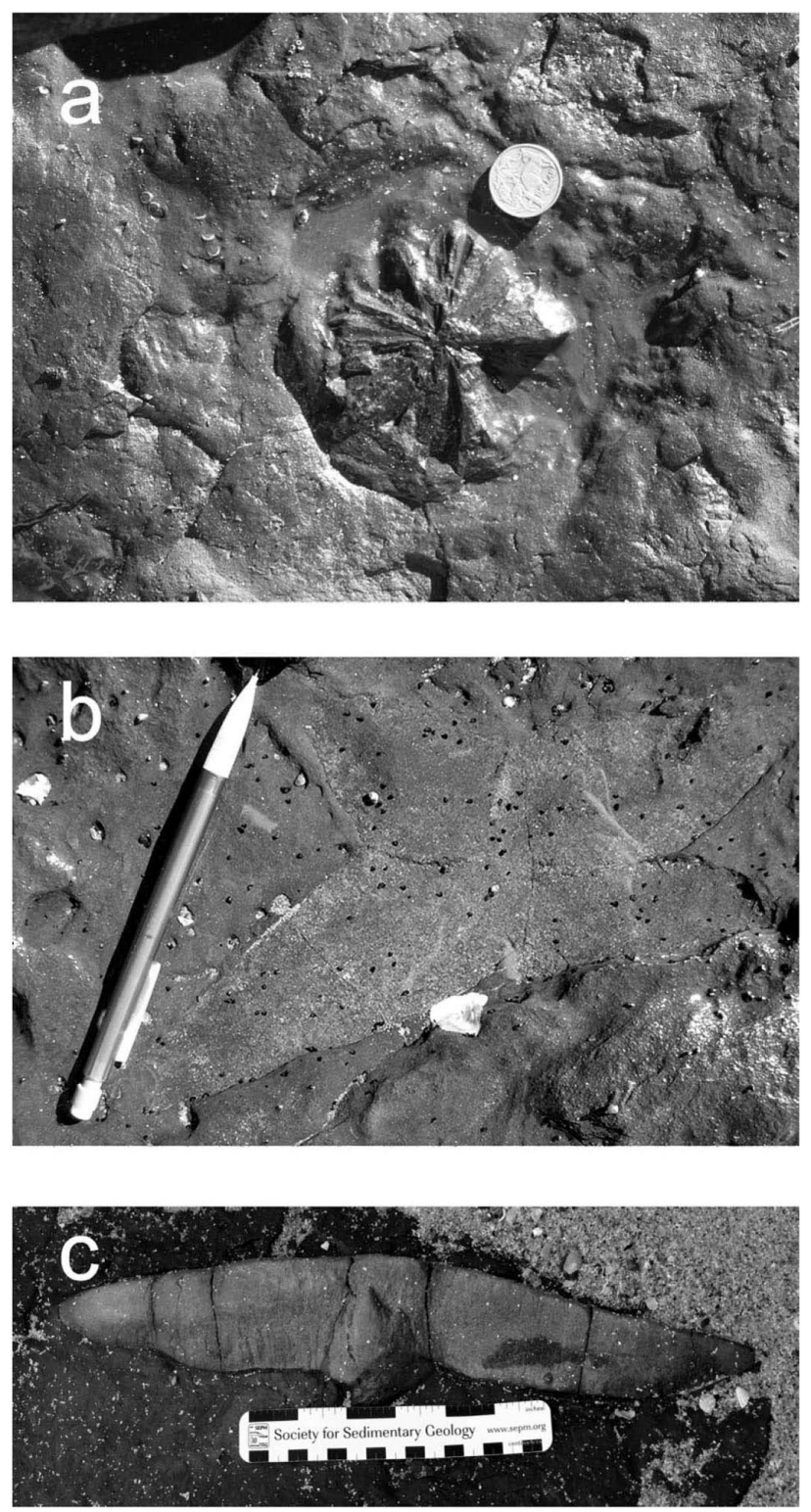

Figure 5. (a) Rosette glendonite from Warden Head (coin is $24 \mathrm{~mm}$ in diameter). (b) Stellate glendonite from Huskisson (pencil is $10 \mathrm{~cm}$ long). (c) Bladed glendonite from Huskisson (16 cm scale). See Table 1 for UTM coordinates.

hummocky cross-stratified, convolute-bedded, and crossbedded sandstone lies above the basal conglomerate and is overlain by parallel laminated sandstone beds locally containing load casts and flame structures. The uppermost beds of FA6 consist of clean quartzose sandstone that contains dish structures. Coarse sandstone dykes and intrusions $<1 \mathrm{~m}$ in length penetrate into the beds underlying FA6 and the beds overlying the dish structures at Lagoon Head. Sparse D. habichi and Asterosoma burrows occur in the uppermost beds. Apart from this, FA6 appears to lack bioturbation. Two major FA6 bodies are at Lagoon Head (Figure 6, Sections 1-3) and at Farnham Point (Figure 6, Section 14). Because similar facies are found at both sections above and below the FA6 bodies, they are interpreted to lie at the same stratigraphic level in the formation.
Interpretation FA6 contains evidence for partly to fully turbulent, unidirectional flows and combined flows at lower shoreface depths. Planar laminated beds imply upper flow regime conditions, and dish structures in the top beds suggest that the flow was at times liquidized (Lowe \& LoPiccolo 1974). Sandstone dykes that penetrate into the underlying strata also record water escape (Lowe 1975). Deformational features such as load and flame structures indicate the rapid emplacement of sands that prevented the dewatering of the underlying silts (Lowe 1975). Although previously interpreted as deepwater canyon fills internally dominated by turbidites (Eyles et al. 1998), this association contains local hummocky cross-stratification, which provides evidence for shore- face water depths. Rare D. habichi burrows, components of the Skolithos Ichnofacies, are present in the tops of beds of FA6. FA6 is interpreted to have been deposited in shoreface to offshore transition depths.

\section{Facies association 7: soft-sediment-deformed strata}

Description FA7 includes chaotically bedded intervals of FA1, FA2 and FA4 that reach a maximum thickness of $7 \mathrm{~m}$. Penecontemporaneous soft-sediment deformation is pervasive throughout FA7. Recumbent soft-sediment folds are ubiquitous in this association, and load balls are locally present. Sandstone dykes are contained in FA7 and the overlying sediments. FA7 is confined stratigraphically to a single, discrete interval in the formation. Cross-cutting relationships indicate that the rosette glendonites present in FA7 formed in situ following deformation.

Interpretation FA7 is interpreted as slump masses. Although there are no bathymetric constraints for FA7, association with FA1, FA2, and FA4 indicates that the slump event(s) occurred in offshore to shelfal water depths.

\section{Facies association 8: tuffaceous siltstone and claystone}

Description FA8 comprises siltstone and claystone of reworked volcanic tephra. Occasional coarse plagioclase crystals and clasts of pumice are preserved in addition to fine ash. Although sedimentary structures are rare in this facies, ripple cross-lamination, where present, indicates locally an eastward current direction. Trace fossils are also rare, but several ichnogenera are reported (Table 2). FA8 becomes increasingly abundant in the upper portion of the formation and is commonly interbedded with FA2 and FA4.

Interpretation Based on its association with FA2 and FA4, FA8 corresponds to deposition in shelfal to offshore transition depths and records settling through the marine water column of volcanic fallout following regional explosive volcanic activity.

\section{Lithostratigraphy}

The Wandrawandian Siltstone can be divided into five informal members (Figure 6) on the basis of the previously defined facies associations. Genetic relationships among 


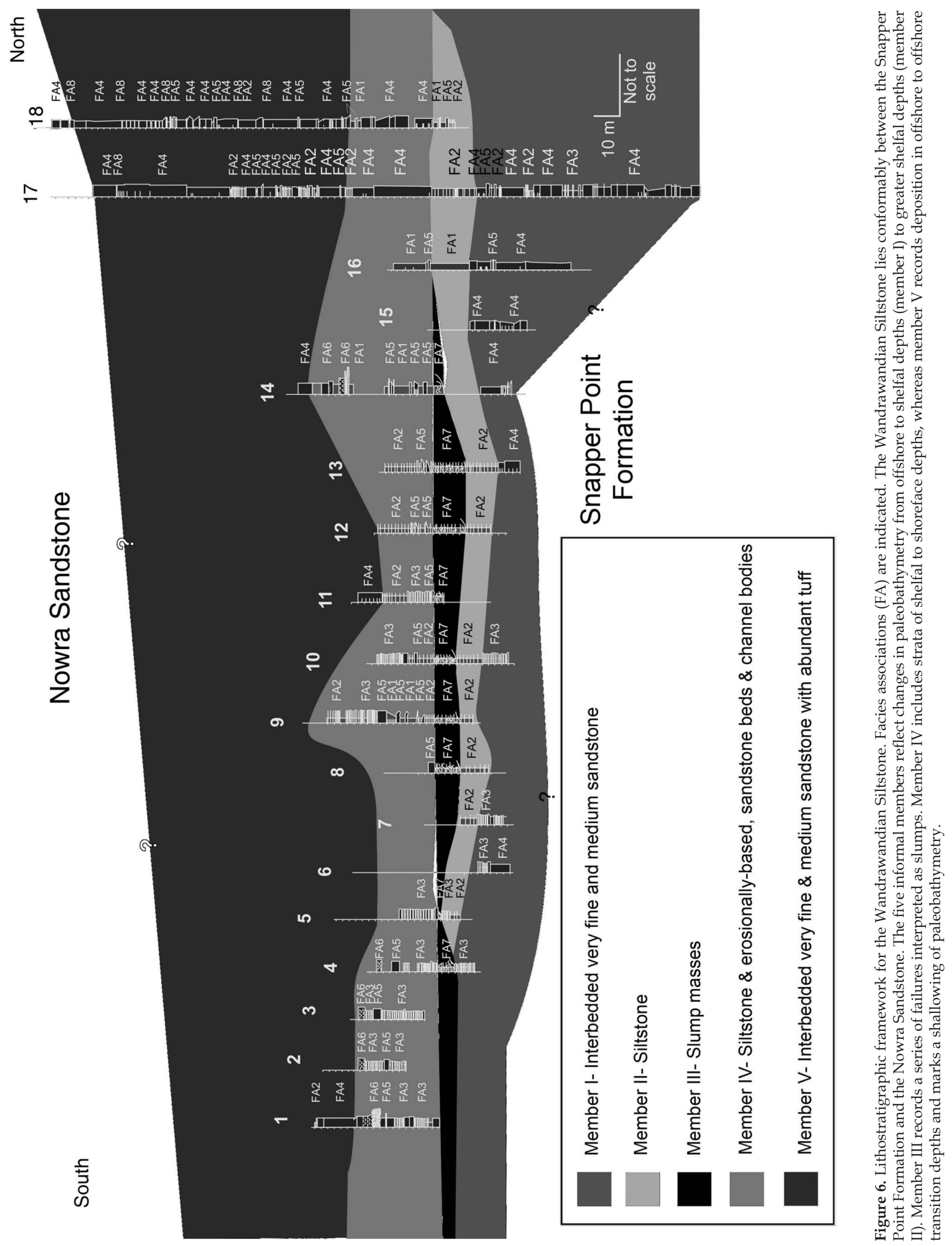


the facies associations and the identification of key surfaces allow for interpretation of the Wandrawandian Siltstone in terms of changes in depositional environment and fluctuations in paleobathymetry (Figure 4). The five informal members are as follows, from the base to the top of the formation: member I, interbedded/admixed sandstone and siltstone; member II, siltstone; member III, slumped masses of members I and II; member IV, siltstone and erosionally based lensoidal sandstone beds and channel bodies; and member V, interbedded/admixed sand and silt with abundant tuffs.

\section{Member I: Interbedded/admixed sandstone and siltstone}

Member I consists predominantly of FA4 (admixed siltstone and very-fine-to medium-grained sandstone), but includes minor proportions of FA3 (interbedded tabular sandstone and siltstone), FA2 (siltstone with minor interbedded or admixed sandstone), and FA5 (channelform sandstone). This member has a maximum thickness of $67 \mathrm{~m}$ (Figure 6, Section 17). Only one outcrop section located south of Berrara Headlands (Figure 6, Section 14) exposes the contact between the Snapper Point Formation and the Wandrawandian Siltstone. There, and in both cores examined, the contact is gradational, marked by fining upwards over $\sim 60 \mathrm{~cm}$ from the coarse-grained sandstone of the Snapper Point Formation to admixed siltstone and sandstone of member I. At the Berrara Headlands outcrop, however, the Snapper Point Formation and the Wandrawandian Siltstone are exposed in a horst block in which local brecciation and sedimentary injection features occur in the basal $1 \mathrm{~m}$ of the Wandrawandian Siltstone, presumably caused by post-mid-Permian brittle deformation.

In Sections 4, 6, 7 and 10, member I fines upwards from FA4 into FA3 and FA2. In other sections, member I consists predominantly of FA4 with minor beds of FA5, FA3, and FA2. Horizons in member I contain the largest and mostabundant outsized clasts in the formation, reaching up to $2 \mathrm{~m}$ in diameter. The presence of glendonites near the top of this member suggests cold seawater temperatures. The abrupt transition from the coarser-grained lower shoreface deposits of the Snapper Point Formation to admixed finegrained sandstone and siltstone (FA4), which record mainly offshore to offshore transition water depths, indicates deepening. Further deepening is recorded in the southern part of the area by the transition from fine-grained sandstone (FA4) to inter- bedded and admixed siltstone and sandstone (FA2 and FA3) of offshore to shelfal depths. As such, member I records an initial marine transgression.

\section{Member II: Siltstone}

Member II includes siltstones of FA1 and siltstone with interbedded or admixed sand of FA2. FA3 (interbedded tabular sandstone and siltstone) is a minor constituent. This member, $<15 \mathrm{~m}$ thick, is not laterally persistent throughout the field area and appears to thin and pinch out southward at Dolphin Point (Figure 6, Section 5). The apparent thinning and pinching out is attributed to downcutting into member II by slump sheets of the overlying member.

This member records quiet marine waters below wavebase. Sandstone most likely represents occasional disturbance by storm-related currents and/or waves. Coquinite horizons contain abundant invertebrate fossils, many of which are preserved with delicate features such as spines and fenestrae intact. The fossils probably did not endure much transport and reworking, although winnowing by currents as a method of concentration is not precluded. Outsized clasts and glendonites are common. Volcanic ash first appears in the Wandrawandian Siltstone in member II, at Dolphin Point South (Figure 6, Section 5) and at Rennie's Beach (Figure 6, Section 8). Member II represents a further deepening from the mainly offshore water depths of member I to shelfal environments.

\section{Member III: Slumped masses of members I and II}

Member III, which contains chaotically bedded masses of members I and II, records a series of failures of the submarine sediment surface. Member III reaches a maximum thickness of $10 \mathrm{~m}$ at Warden Head and Ulladulla North Head, south (Figure 6, Sections 11 and 12). This member does not persist along the entire outcrop belt, but is widely exposed north and south of Ulladulla and at Berrara Headland (Figure 6), which are separated by $\sim 30 \mathrm{~km}$. It appears to pinch out to the south at Lagoon Head and to the north at Berrara Headland (Figure 6, Sections 4 and 14, respectively). Although relatively thin, member III is exposed over a large area and is of regional significance.

No direct indications of bathymetry are present in member III, but based on the facies associations present (FA7, which comprises slumped beds of FA1, FA2, and FA4), it is inferred to have been deposited in offshore to shelfal water depths. Member III consists of a slump sheet overlain by a slump scar at Warden Head. At this locality, Smith (2000) noted that the slump scar and sand dykes with en échelon segmentation indicate an easterly paleoslope. By measuring crinoid deformation in slump lobes, Smith (2000) found that slump sheet orientation was variable. The pattern of strain indicates flexural flow folding, where incompetent sediment passively records deformation (Twiss \& Moores 1992).

\section{Member IV: Siltstone and erosionally based lensoid sand- stone beds}

Member IV consists of erosionally based lenses of sandstone and conglomerate beds of FA5 and FA6 enclosed within the finer-grained facies of FA1, FA2, FA3 and FA4 (siltstones and fine-grained sandstones). Member IV reaches $32 \mathrm{~m}$ at its thickest (Warden Head South: Figure 6, Section 9), but typically 10-20 m are recorded.

Both the lower and upper parts of member IV contain an array of FA5 beds hosted in finer grained facies (FA1, FA2 and FA3). Large-scale channel forms (FA6) that record 
deposition from sediment-charged flows are present in the upper part of member IV. At Lagoon Head (Figure 6, Sections 1-4), the channel appears to be a single-storey body, whereas at Farnham Head (Figure 6, Section 14), multiple storeys are preserved. The presence of FA6 at these two geographically separate localities makes this stratigraphic horizon regionally significant. Channel incision into underlying strata suggests shallowing of water depth of $\sim 50 \mathrm{~m}$.

Surfaces containing the Glossifungites Ichnofacies provide evidence for erosion and/or hiatus (MacEachern et al. 1992b). The palimpsest assemblages are commonly overlain by beds of FA5, which are typically $<1 \mathrm{~m}$ thick. These beds may record storm deposition or may be distal equivalents of FA6.

Overall, member IV coarsens upwards from siltstone (FA2) deposited in shelfal depths to interbedded sandstone and siltstone (FA3) and/or fine-grained sandstone and admixed siltstone (FA4) of mainly offshore depths. The largescale channels are interpreted to be at the same stratigraphic horizon (Sections 1-4, 14), based on correlation of facies, which suggests a shallowing of the environment to shoreface depths. This interpretation suggests that the bases of these channels may represent a sequence boundary (Van Wagoner et al. 1988). Inferred formative depths of the enclosing sediments vary from shelfal at the base to offshore above the channels, indicating a drastic change in depositional environment. The abrupt upward transition from the channel deposits to offshore sediments indicates that deposition only recommenced once deepening had occurred again.

\section{Member V: Interbedded/admixed sand and silt with abun- dant tuffs}

Member V is chiefly composed of FA4 (admixed sandstone and siltstone), although discrete beds of reworked volcanic tephra (FA8) are abundant. FA2 (siltstone with minor sand interbeds) and FA5 (channelized sands) are minor constituents. Member V is well exposed in the north at Cabbage Tree Point (Figure 6, Section 18), with a thickness of nearly $80 \mathrm{~m}$, but at Lagoon Head, only $12 \mathrm{~m}$ of member V are exposed. The member is incompletely exposed in the southern part of the outcrop belt or thickens towards the north.

Member $\mathrm{V}$ coarsens upwards gradationally into the Nowra Sandstone. Le Roux \& Jones (1994) documented the contact between the Nowra Sandstone and the Wandrawandian Siltstone at Crookhaven Head $(\sim 15 \mathrm{~km}$ north of the field area). They interpreted the lensoidal beds below the contact with the Nowra Sandstone as storm-redeposited beds. These may be beds of FA5, although at other exposures where the contact is exposed, like Montague Roadstead (Figure 6, Section 18), the uppermost beds do not appear erosionally based but seem to be flat-lying. The lack of lensoidal beds within similar stratigraphic horizons elsewhere in the field area may, however, be an artifact of the orientation of the outcrop relative to strike. All of the beds may in fact be channelized, although that geometry is visible only at Crookhaven Head.

Member $\mathrm{V}$ coarsens upward and contains siltstone with minor sandstone. Similar to member IV, it contains beds of FA5 enclosed within finer grained facies of FA2 and FA4, particularly in the lower half of the member. High-frequency fluctuations in depositional environment are inferred in member $\mathrm{V}$ on the basis of subtle changes in lithology and ichnofabric. Furthermore, the increasing abundance of FA8 (tuffaceous siltstone and claystone) implies explosive volcanism coeval with the deposition of member V. Overall, this member records a shallowing from offshore to offshore transition depths.

\section{Discussion}

The lithologies present in the Wandrawandian Siltstone are consistent with deposition in shelf to lower shoreface environments. The base of the formation is marked by transgression with lower shoreface deposits of the upper Snapper Point Formation overlain by mainly offshore deposits of member I (interbedded/admixed sandstone and siltstone). Deepening continued to increase throughout the deposition of member II (siltstone), in shelfal water depths. Seafloor failure followed, creating the slumped masses of member III. Overall, the depositional environment shallowed from shelfal depths to offshore depths in member IV (siltstone and erosionally based lensoidal sandstone beds), although large- scale channels inferred to be present at the same stratigraphic horizon indicate a sudden shallowing to shoreface depths. Member V (interbedded/admixed sand and silt with abundant tuffs) records continued subtle fluctuations in depositional environment from offshore to offshore transition depths.

A number of explanations for the marine transgression represented by members I (interbedded/admixed sandstone and siltstone) and II (siltstone) can be explored. One potential explanation is a modest return to glacial conditions. Glendonites and ice-rafted debris are common in both members I and II, and member II contains the largest and greatest abundance of ice-rafted debris of any of the members. If ice built up significantly in the region, even as present as alpine glaciers, the relative rise in sea-level could reflect flooding caused by glacial loading and regional subsidence along the continental margin. Uncertainty remains regarding the amount of ice present and whether its presence reflects permanent or seasonal ice build up. Despite the lack of evidence for terrestrial ice, the presence of clasts up to $2 \mathrm{~m}$ in diameter preserved in member II would argue for at least minor glaciers in the region because the ability for river ice to transport such large clasts would be limited.

However, this marine transgression can be correlated throughout the Bowen-Gunnedah-Sydney Basin System (Fielding et al. 1990; Tye et al. 1996). Because of the interregional extent of transgression, glacial loading is unlikely to be a plausible explanation for the deepening recorded in members I and II. The transgression is thought to coincide with the onset of thermal passive subsidence during the deposition of the upper Snapper Point Formation and the Wandrawandian Siltstone (Veevers et al. 1994; Tye et al. 1996; Fielding et al. 2001). And although foreland loading could also produce deepening (Cant \& Stockmal 1993), no evidence of foreland loading is present in members I or II. 
The cause of the slumping in member III remains equivocal. Plausible mechanisms of slump emplacement include: an abrupt rise relative sea-level, increased rates of sedimentation, or seismicity associated with either glacio-isostasy or with the onset of the Hunter-Bowen Contractional Event. Maslin et al. (2004) suggested that high-latitude slumps and slides associated with the Last Glacial Maximum (e.g. Støregga Slide) occurred concurrently with the maximum rate of eustatic sea-level rise. Glacial retreat could have reduced vertical stress on the crust (Meigs \& Sauber 2000), producing seismicity in the region.

Comparison of the Wandrawandian Siltstone and the Moah Creek beds in Queensland led Shi \& Du (2003) to propose that earthquakes associated with the onset of foreland loading triggered slumping in the Wandrawandian Siltstone. The Moah Creek beds, however, record activity on the orogenic margin of the Bowen Basin, whereas the Wandrawandian Siltstone was deposited on the cratonic margin (Tye et al. 1996; Fielding et al. 1997). Additionally, the ages of the two horizons have not been confidently linked, and the slumps in the Moah Creek beds may have occurred at a time significantly later than those in the Wandrawandian Siltstone. Furthermore, the slumping is confined to a discrete horizon, and the lack of further constraints on its origin prevents an explanation that can be tied unequivocally to glacial controls or foreland loading. No tectonic activity is required for the deformation because increased water depth alone could have provided a trigger for slumping.

Members IV (siltstone and erosionally based lensoid sandstone beds) and V (interbedded/admixed sand and silt with abundant tuffs) record high-frequency paleobathymetric fluctuations that probably responded to glacial cycles. A large channel, unique to a discrete stratigraphic horizon in member IV, marks a rapid shallowing from offshore to lower shoreface depths. In an ice-proximal setting, deglaciation and subsequent isostatic rebound would cause shallowing, promoting incision and deposition of storm-modified partially liquefied flow deposits. An overall decrease in size and proportions of ice-rafted debris in members IV and $\mathrm{V}$ indicates that transport of material by local ice decreased during the deposition of these members (Figure 4).

Although member II (siltstone) records the first appearance of FA8 (volcanic tephra) in the Wandrawandian Siltstone, FA8 increases in abundance throughout member V. The tuffs could mark the onset of subduction- related volcanism in the region, although the location of any such subduction zone is unknown. Deposition of the tuffs occurred by air fall, and unlike tephra seen in later Permian strata, the fallout is considered to have been some distance from the source (Shaw et al. 1991). Veevers et al. (1994) considered the tuffs in the Wandrawandian Siltstone to be associated with nascent orogenesis. Runnegar (1980) noted common, thin ash beds in the upper Wandrawandian Siltstone, and this work recognizes over 20 tuff beds at different stratigraphic intervals.

Although ice-rafted debris indicates that ice had been present throughout much of the deposition of the Wandrawandian Siltstone, the origin of the ice has been debated. Eyles et al. (1997) hypothesized that clast-rich horizons in the
Shoalhaven Group of the Sydney Basin were derived from icebergs calved off the margins of a marine-based ice sheet in Antarctica during Heinrich Events. Our observations are consistent with the studies of Brown (1925) and Tye et al. (1996), which suggested that ice-rafted debris was derived from nearby igneous, metamorphic and sedimentary rocks. As such, an Antarctic source of icebergs seems unlikely.

The development of modest glaciers in this region during the Kungurian would have been promoted by its highlatitude position and the presence of highlands to the west (Powell \& Li 1994; Veevers et al. 1994). The record of cold climate in the Sydney Basin extends back to the Wasp Head Formation, and ice-rafted debris is a common feature of the marine environments of the Talaterang and Shoalhaven Groups (Gostin 1968; Gostin \& Herbert 1973; Tye et al. 1996; Eyles et al. 1997). Glendonites, although common, are restricted to the relatively finer grained formations such as the Pebbley Beach Formation, the Wandrawandian Siltstone, the Berry Siltstone, and the Broughton Formation (Carr et al. 1989).

The Sakmarian Pebbley Beach Formation displays similar stratigraphic patterns with estuarine channel incision occurring in principally offshore marine deposits, indicative of abrupt drops in relative sea-level comparable in magnitude to the shallowing marked by the large-scale channels seen in the Wandrawandian Siltstone (Tye et al. 1996; Bann et al. 2004; Fielding et al. 2006). The proportions of ice-rafted debris are greater in underlying formations, and the timing of deposition, especially that of the Pebbley Beach Formation, corresponds to well-documented glacial episodes in Australia and Gondwana (Crowell 1999). Outside eastern Australia, little evidence for glacially influenced sedimentation exists beyond the Sakmarian (Isbell et al. 2003). The presence of cool climate indicators throughout the Wandrawandian Siltstone could indicate the presence of small alpine glaciers in the hinterland or the development of seasonal sea ice.

\section{Conclusions}

The Wandrawandian Siltstone can be divided into eight facies associations based on lithology, sedimentary structures and ichnofacies, and resolved into five informal members: member I, interbedded/admixed sandstone and siltstone that marks a marine transgression from shoreface to offshore depths; member II, siltstone that records shelfal water depths; member III, slumped masses of members I and II, which are inferred to have been deposited in shelfal to offshore depths; member IV siltstone and erosionally based lensoid sandstone beds and channel bodies of mainly offshore to shoreface depths; and member V, interbedded/admixed sand and silt with abundant tuffs of predominantly offshore to offshore transition depths. These members are inferred to correspond to fluctuations in relative sea-level.

In the Early to early Middle Permian strata of the Shoalhaven Group, high-frequency fluctuations in depositional environment have been documented (Bann 1998; Bann et al. 2004) and are likely driven by glacial cycles and glacio- 
eustatic sea-level variation. Ice-rafted debris indicates the presence of floating ice masses during the deposition of the Wandrawandian Siltstone, although the size and abundance of the ice-rafted debris decreases upward through the formation. Ice was not likely derived from Antarctica because many of the dropstones are lithologically similar to basement rocks that crop out in the immediate hinterland. The Wandrawandian Siltstone probably marks modest glacial conditions, possibly in the form of alpine glaciers or the development of sea ice or seasonal river ice. The contribution of glacial isostasy and eustasy to relative sea-level fluctuations in the Wandrawandian Siltstone is not entirely clear, although cold climate indicators (ice-rafted debris, glendonites) throughout the formation indicate the persistence of cold conditions during the deposition of the Wandrawandian Siltstone.

The underlying tectonic regime probably influenced lower-order fluctuations of greater magnitude, e.g. the transgression noted at the base of the Wandrawandian Siltstone associated with thermal sag and the possible influences of contraction. The overall sheet-like architecture of the Wandrawandian Siltstone suggests that deposition took place in a thermally subsiding basin, although tuffs point towards explosive volcanism that could be associated with distal subduction.

\section{Acknowledgments}

SGT was supported by the Coffman Fellowship provided by the Department of Geosciences at the University of Nebraska-Lincoln. Funding was provided by National Science Foundation grant EAR-0417578 to CRF and TDF. Access to cores was provided by the NSW Geological Survey Londonderry Drill Core Library. We would like to thank David Loope and Michael Rygel for their reviews of an earlier version of the manuscript. The manuscript was greatly improved by reviews from John Roberts and Brian Jones.

\section{References}

Arditto P. A. 2001. Distribution and hydrocarbon potential of the Permian Nowra Sandstone, southern Sydney Basin, New South Wales, Australia. In: Hill K. C. and Bernecker T., eds. Eastern Australasian Basins Symposium: a Refocused Energy Perspective for the Future, pp. 239-249. Petroleum Exploration Society of Australia Special Publication.

Bann K. L. 1998. Ichnology and sequence stratigraphy of the Early Permian Pebbley Beach Formation and Snapper Point Formation in the southern Sydney Basin. PhD thesis, University of Wollongong, Wollongong.

Bann K. L., Fielding C. R., Maceachern J. A., and Tye S. C. 2004. Differentiation of estuarine and offshore marine deposits using integrated ichnology and sedimentology: Permian Pebbley Beach Formation, Sydney Basin Australia. In: Mcllroy D. ed. Application of Ichnology to Palaeoenvironmental and Stratigraphic Analysis, pp. 179-212. Geological Society of London Special Publication 228.

Battersby D. G. 1981. New discoveries in the Surat/Bowen Basin. APEA Journal 21, 39-44.
Briggs D. J. C. 1998. Permian Productidina and Strophalosiidina from the Sydney-Bowen Basin and New England Orogen; systematics and biostratigraphic significance. Australasian Association of Palaeontologists Memoir 19.

Bromley R. G. 1996. Trace Fossils: Biology, Taphonomy, and Applications (2nd edition). Chapman and Hall, London.

Brown I. A. 1925. Notes on the occurrence of glendonites and glacial erratics in Upper Marine Beds at Ulladulla, NSW. Proceedings of the Linnean Society of New South Wales 50, 25-31.

Cant D. J. and StockmaL G. S. 1993. Some controls on sedimentary sequences in foreland basins: examples from the Alberta Basin. In: Frostick L. E. ed. Tectonic Controls and Signatures in Sedimentary Successions, pp. 49-65. Blackwell Scientific Publications, Oxford.

Carr P. F. 1998. Subduction-related Late Permian shoshonites of the Sydney Basin, Australia. Mineralogy and Petrology 63, 49-71.

Carr P. F., Jones B. G., and Middleton R. B. 1989. Precursor and formation of glendonites in the Sydney Basin. Australian Mineralogist 4, 3-12.

Crowell J. C. 1999. Pre-Mesozoic ice ages: their bearing on understanding the climate system. Geological Society of America Memoir 192.

David T. W. E., Taylor T. G., Woolnough W. G., and Foxall N. G. 1905. Occurrence of the pseudomorph glendonite in New South Wales, with notes on the microscopic and crystallographic characters. Geological Survey of New South Wales Records 8, 161-179.

Eyles C. H., Eyles N., and Gostin V. A. 1998. Facies and allostratigraphy of high-latitude, glacially influenced marine strata of the Early Permian southern Sydney Basin, Australia. Sedimentology 45, 121-161.

Eyles N., Eyles C. H., and Gostin V. A. 1997. Iceberg rafting and scouring in the Early Permian Shoalhaven Group of New South Wales, Australia: evidence of Heinrich-like events? Palaeogeography, Palaeoclimatology, Palaeoecology 136, 1 -17.

Fielding C. R., Bann K. L., Maceachern J. A., Tye S. C., and Jones B. G. 2006. Cyclicity in the nearshore marine to coastal Lower Permian Pebbley Beach Formation, southern Sydney Basin, Australia: a record of relative sea-level fluctuations at the close of the Late Palaeozoic Gondwanan Ice Age. Sedimentology 53, 435-463.

Fielding C. R., Falkner A. J., Kassan J., and Draper J. J. 1990. Permian and Triassic depositional systems in the Bowen Basin. In: Bowen Basin Symposium Proceedings, pp. 21-25. Geological Society of Australia, Queensland Division, Brisbane.

Fielding C. R., Sliwa R., Holcombe R. J., and Jones A. T. 2001. A new palaeogeographic synthesis for the Bowen, Gunnedah, and Sydney basins of Eastern Australia. In: Hill K. C. and Bernecker T., eds. Eastern Australasian Basins Symposium: a Refocused Energy Perspective for the Future, pp. 269-278. Petroleum Exploration Society of Australia Special Publication.

Fielding C. R., Stephens C. J., and Holcombe R. J. 1997. Submarine mass-wasting deposits as an indicator of the onset of foreland thrust loading - Late Permian Bowen Basin, Queensland, Australia. Terra Nova 9, 14-18.

Frey R. W. and Pemberton S. G. 1984. Trace fossils facies models. In: Walker R. G. ed. Facies Models (2nd edition), pp. 189-207. Geoscience Canada, Toronto.

Galloway W. E. and Hobday D. K. 1996. Terrigenous Clastic Depositional Systems (2nd edition). Springer, Berlin.

Gostin V. A. 1968. Stratigraphy and sedimentology of the Lower Permian sequence in the Durras-Ulladulla area, Sydney Basin, New South Wales. PhD thesis, Australian National University, Canberra (unpubl.). 
Gostin V. A. and Herbert C. 1973. Stratigraphy of the Upper Carboniferous and Lower Permian sequence, southern Sydney Basin. Journal of the Geological Society of Australia 20, 49-70.

Gradstein F. M., Ogg J. G., and Smith A. G. 2005. A Geologic Time Scale 2004. Cambridge University Press, Cambridge.

Herbert C. 1980. Southwestern Sydney Basin. In: Herbert C. and Helby R., eds. A Guide to the Sydney Basin, pp. 82-99. Geological Survey of New South Wales Bulletin 26.

Isbell J. L., Miller M. F., Wolfe K. L., and Lenaker P. A. 2003. Timing of late Paleozoic glaciation in Gondwana: was glaciation responsible for the development of Northern Hemisphere cyclothems? In: Chan M. A. and Archer A. W., eds. Extreme Depositional Environments: Mega End Members in Geologic Time, pp. 5-24. Geological Society of America Special Paper 370.

Le Roux J. P. and Jones B. G. 1994. Lithostratigraphy and depositional environment of the Permian Nowra Sandstone in the southwestern Sydney Basin, Australia. Australian Journal of Earth Sciences 41, 191-203.

Lowe D. R. 1975. Water escape structures in coarse-grained sediments. Sedimentology 22, 157-204.

Lowe D. R. and Lopiccolo R. D. 1974. The characteristics and origins of dish and pillar structures. Journal of Sedimentary Petrology 44, 484-501.

Maceachern J. A., Bechel D. J., and Pemberton S. G. 1992a. Ichnology and sedimentology of transgressive deposits, transgressively related deposits and transgressive systems tracts in the Viking Formation of Alberta. Society of Economic Paleontologists and Mineralogists Core Workshop 17, 251-290.

Maceachern J. A., Raychaudhuri I., and Pemberton S. G. 1992b. Stratigraphic applications of the Glossifungites Ichnofacies: delineating discontinuities in the rock record. Society of Economic Paleontologists and Mineralogists Core Workshop 17, 169-198.

Maslin M., Owen M., Day S., and Long D. 2004. Linking continental- slope failures and climate change: testing the clathrate gun hypothesis. Geology 32, 53-56.

Meigs A. and Sauber J. 2000. Southern Alaska as an example of the long-term consequences of mountain building under the influence of glaciers. Quaternary Science Reviews 19, 1543-1562.

Murray C. G. 1990. Tectonic evolution and metallogeny of the Bowen Basin. Bowen Basin Symposium Proceedings, pp. 201212. Geological Society of Australia, Queensland Division, Brisbane.

Pauly H. 1963. Ikaite, a new mineral from Greenland. Arctic 16, 263-264.

Pemberton S. G., Maceachern J. A., and Frey R. W. 1992. Trace fossil facies models: environmental and allostratigraphic significance. In: Walker R. G. and James N. P., eds. Facies Models: Response to Sea Level Change, pp. 47-72. Geological Association of Canada, Toronto.

Powell C. McA. and Li Z. X. 1994. Reconstruction of the Panthalassan margin of Gondwanaland. In: Veevers J. J. and Powell C. McA., eds. Permian-Triassic Pangean Basins and Foldbelts along the Panthalassan Margin of Gondwanaland, pp. 5-9. Geological Society of America Special Paper 184.

Ramli N. and Crook K. A. W. 1978. Early Permian depositional environments, southern Sydney Basin. APEA Journal 18, 70-76.

Reineck H. E. 1967. Layered sediments of tidal flats, beaches and shelf bottoms of the North Sea. In: Lauff G. H. ed. Estuaries, pp. 191-208. American Association for the Advancement of Science Publication 83.

Roberts J., Offler R., and Fanning M. 2006. Carboniferous to Lower Permian stratigraphy of the southern Tamworth Belt, south- ern New England Orogen, Australia: boundary sequences of the Werrie and Rouchel blocks. Australian Journal of Earth Sciences 53, 249-284.

Runnegar B. 1980. Montague Roadstead, Jervis Bay (Early Permian, Shoalhaven Group). In: Herbert C. and Helby R., eds. A Guide to the Sydney Basin, pp. 531-537. Geological Survey of New South Wales Bulletin 26.

Savrda C. E., Bottjer D. J., and Gorsline D. S. 1984. Development of a comprehensive oxygen-deficient marine biofacies model: evidence from Santa Monica, Sand Pedro, and Santa Barbara Basins, California continental borderland. AAPG Bulletin 68, 1179-1192.

Scheibner E. 1974. A plate tectonic model of the Palaeozoic tectonic history of New South Wales. Journal of the Geological Society of Australia 20, 405-426.

Seilacher A. 1964. Biogenic sedimentary structures. In: Imbrie J. and Newell N., eds. Approaches to Paleoecology, pp. 296-316. Wiley, New York.

Shaw S. E., Conaghan P. J., and Flood R. H. 1991. Late Permian and Triassic igneous activity in the New England Batholith and contemporaneous tephra in the Sydney and Gunnedah Basins. In: 25th Newcastle Symposium on Advances in the Study of the Sydney Basin, pp. 44-51. Department of Geology, University of Newcastle, Newcastle.

Shi G. R. and Du Y. 2003. Soft-sediment deformation structures in the Middle Permian Wandrawandian Siltstone, Southern Sydney Basin: implications for depositional environment and basin tectonics. In: Proceedings of the 35th Symposium on Advances in the Study of the Sydney Basin, pp. 307-314. University of Wollongong, Wollongong.

Smith J. V. 2000. Flow pattern within a Permian submarine slump recorded by oblique folds and deformed fossils, Ulladulla, southeastern Australia. Sedimentology 47, 357-366.

Suess E., Balzer W., Hesse K-F., Muller P. J., Ungerer C. A., and Wefer G. 1982. Calcium carbonate hexahydrate from organic rich sediments of the Antarctic shelf: precursors of glendonites. Science 216, 1128-1131.

Taylor A. M. and Goldring R. 1993. Description and analysis of bioturbation and ichnofabric. Journal of the Geological Society of London 150, 141-148.

Twiss R. J. and Moores E. M. 1992. Structural Geology. W. H. Freeman, New York.

Tye S. C., Fielding C. R., and Jones B. G. 1996. Stratigraphy and sedimentology of the Permian Talaterang and Shoalhaven Groups in the southernmost Sydney Basin, New South Wales. Australian Journal of Earth Sciences 43, 57-69.

Van Wagoner J. C., Posamentier H. W., Mitchum R. M., Vail P. R., Sarg J. F., Loutit T. S., and Hardenbol J. 1988. An overview of the fundamentals of sequence stratigraphy and key definitions. In: Wilgus C. K., Hastings B. S., Posamentier H. W., Van Wagoner J. C., Ross C. A., and Kendall C. G. St C., eds. Sea-Level Changes: an Integrated Approach, pp. 39-45. Society of Economic Paleontologists and Mineralogists Special Publication 42.

Veevers J. J., Conaghan P. J., and Powell C. McA. 1994. Eastern Australia. In: Veevers J. J. and Powell C. McA., eds. PermianTriassic Pangean Basins and Foldbelts along the Panthalassan Margin of Gondwanaland, pp. 11-171. Geological Society of America Special Paper 184.

Veevers J. J. and Powell C. McA. 1987. Late Paleozoic glacial episodes in Gondwanaland reflected in transgressive-regressive depositional sequences in Euramerica. Geological Society of America Bulletin 98, 475-487. 